\title{
Overview of the 2007 and 2008 campaigns conducted as part of the Greenland Summit Halogen-HO ${ }_{x}$ Experiment (GSHOX)
}

\author{
J. L. Thomas ${ }^{1,2}$, J. E. Dibb ${ }^{3}$, J. Stutz ${ }^{1}$, R. von Glasow ${ }^{4}$, S. Brooks ${ }^{5}$, L. G. Huey ${ }^{6}$, and B. Lefer ${ }^{7}$ \\ ${ }^{1}$ Department of Atmospheric and Oceanic Sciences, University of California, Los Angeles, CA 90095, USA \\ ${ }^{2}$ UPMC Univ. Paris 06, UMR8190, CNRS/INSU - Univ. Versailles St.-Quentin, LATMOS-IPSL, Paris, France \\ ${ }^{3}$ Institute for the Study of Earth, Oceans, and Space, University of New Hampshire, Durham, NH 03824, USA \\ ${ }^{4}$ School of Environmental Sciences, University of East Anglia, Norwich, NR4 7TJ, UK \\ ${ }^{5}$ NOAA ATDD, 456 S. Illinois Ave, P.O. Box 2456, Oak Ridge, TN 38731, USA \\ ${ }^{6}$ School of Earth and Atmospheric Sciences, Georgia Institute of Technology, Atlanta, GA 30033, USA \\ ${ }^{7}$ Department of Geosciences, University of Houston, TX 77204, USA
}

Correspondence to: J. L. Thomas (jennie.thomas@latmos.ipsl.fr) and J. E. Dibb (jack.dibb@unh.edu)

Received: 12 June 2012 - Published in Atmos. Chem. Phys. Discuss.: 12 July 2012

Revised: 31 October 2012 - Accepted: 1 November 2012 - Published: 16 November 2012

\begin{abstract}
From 10 May through 17 June 2007 and 6 June through 9 July 2008 intensive sampling campaigns at Summit, Greenland confirmed that active bromine chemistry is occurring in and above the snow pack at the highest part of the Greenland ice sheet $\left(72^{\circ} 36^{\prime} \mathrm{N}, 38^{\circ} 25^{\prime} \mathrm{W}\right.$ and $3.2 \mathrm{~km}$ above sea level). Direct measurements found $\mathrm{BrO}$ and soluble gas phase $\mathrm{Br}^{-}$mixing ratios in the low pptv range on many days (maxima $<10 \mathrm{pptv}$ ). Conversion of up to $200 \mathrm{pg} \mathrm{m}^{-3}$ of gaseous elemental mercury (GEM) to reactive gaseous mercury (RGM) and enhanced $\mathrm{OH}$ relative to $\mathrm{HO}_{2}$ plus $\mathrm{RO}_{2}$ confirm that active bromine chemistry is impacting chemical cycles even at such low abundances of reactive bromine species. However, it does not appear that $\mathrm{Br}_{\mathrm{y}}$ chemistry can fully account for observed perturbations to $\mathrm{HO}_{\mathrm{x}}$ partitioning, suggesting unknown additional chemical processes may be important in this unique environment, or that our understanding of coupled $\mathrm{NO}_{\mathrm{x}}-\mathrm{HO}_{\mathrm{x}}-\mathrm{Br}_{\mathrm{y}}$ chemistry above sunlit polar snow is incomplete. Rapid transport from the north Atlantic marine boundary layer occasionally caused enhanced $\mathrm{BrO}$ at Summit (just two such events observed during the 12 weeks of sampling over the two seasons). In general observed reactive bromine was linked to activation of bromide $\left(\mathrm{Br}^{-}\right)$in, and release of reactive bromine from, the snowpack. A coupled snow-atmosphere model simulated observed $\mathrm{NO}$ and $\mathrm{BrO}$ at Summit during a three day interval when winds were weak. The source of $\mathrm{Br}^{-}$in surface and near surface snow at Summit is not entirely clear, but con-
\end{abstract}

centrations were observed to increase when stronger vertical mixing brought free tropospheric air to the surface. Reactive $\mathrm{Br}_{\mathrm{y}}$ mixing ratios above the snow often increased in the day or two following increases in snow concentration, but this response was not consistent. On seasonal time scales concentrations of $\mathrm{Br}^{-}$in snow and reactive bromine in the air were directly related.

\section{Motivation}

In 1998 and 1999 separate research teams at Alert, Summit, South Pole, and Neumayer discovered that sunlight shining on polar snow caused production of $\mathrm{NO}$ and $\mathrm{NO}_{2}$ which were released to the overlying air (Ridley et al., 2000; Honrath et al., 1999; Jones et al., 2000; Davis et al., 2001); for details see Grannas et al. (2007). These findings launched a large number of follow on investigations into snow photochemistry at many field sites and in laboratories (summarized in Grannas et al., 2007). Early results from Summit indicated that emissions of reactive precursors from the snow should lead to large enhancements of $\mathrm{HO}_{\mathrm{x}}$ (e.g., Honrath et al., 2002; Yang et al., 2002), a prediction that was first tested and confirmed in 2003 (Chen et al., 2007; Sjostedt et al., 2007). However, the 2003 campaign found that while the abundance of $\mathrm{HO}_{2}$ plus $\mathrm{RO}_{2}$ was well simulated by a standard homogeneous box model constrained by measured precursors and sinks, 
observed $\mathrm{OH}$ was about twice predicted values on average (Sjostedt et al., 2007). These investigators speculated that active bromine chemistry, well known to convert $\mathrm{HO}_{2}$ to $\mathrm{OH}$, might account for the unexpected partitioning of $\mathrm{HO}_{\mathrm{x}}$ observed at Summit. An obvious, and admitted, problem with this hypothesis is that Summit is very far removed from known sources of bromine and bromide that normally sustain active bromine chemistry. However, recent studies using satellite retrievals of tropospheric $\mathrm{BrO}$ suggest that there is most likely a reservoir of $\mathrm{Br}_{\mathrm{y}}$ in the polar free troposphere (Theys et al., 2011; Roscoe et al., 2012; Choi et al., 2012), which may have an influence on bromine loading in the remote Arctic boundary layer. It is important to note that the impact of $\mathrm{Br}_{\mathrm{y}}$ chemistry on $\mathrm{HO}_{\mathrm{x}}$ partitioning (as well as on $\mathrm{NO}_{\mathrm{x}}$ partitioning, the speciation of atmospheric $\mathrm{Hg}$, and $\mathrm{O}_{3}$ abundance) can be significant even at low levels of active bromine. The Greenland Summit Halogen- $\mathrm{HO}_{\mathrm{x}}$ Experiment (GSHOX) was designed and conducted to confirm or refute whether bromine chemistry was occurring at Summit, and attempt to constrain the source(s) of active bromine if significant abundances were confirmed.

We briefly review the halogen chemistry that motivated the, GSHOX campaigns at Summit (summarized in Fig. 1). Bromine chemistry is well known to impact Arctic boundary layer ozone via the following reactions.

$\mathrm{Br}_{2}+h v \rightarrow 2 \mathrm{Br}$

$\mathrm{Br}+\mathrm{O}_{3} \rightarrow \mathrm{BrO}+\mathrm{O}_{2}$

At Summit, $\mathrm{Br}_{2}$ originates from snow photochemistry involving bromide present in the snowpack. Bromine released from snow can impact $\mathrm{OH}$ levels, via reaction with the hydroperoxyl radical $\left(\mathrm{HO}_{2}\right)$, followed by photolysis of $\mathrm{HOBr}$ (Reactions 3 and 4). Reaction (4) also continues the ozone destruction cycle, via formation of the bromine radical followed by Reaction (2).

$\mathrm{BrO}+\mathrm{HO}_{2} \rightarrow \mathrm{HOBr}+\mathrm{O}_{2}$

$\mathrm{HOBr}+h v \rightarrow \mathrm{OH}+\mathrm{Br}$

Nitrogen oxides from the snowpack are also important, as they determine the rate of ozone formation (reactions not shown) as well as react with bromine monoxide (Reactions 5 and 6).

$\mathrm{BrO}+\mathrm{NO}_{2} \rightarrow \mathrm{BrNO}_{3}$

$\mathrm{BrO}+\mathrm{NO} \rightarrow \mathrm{Br}+\mathrm{NO}_{2}$

Nitrogen oxides also influence the $\mathrm{OH} / \mathrm{HO}_{2}$ ratio via $\mathrm{HO}_{\mathrm{x}}$ inter-conversion reactions, such as Reaction (7).

$\mathrm{HO}_{2}+\mathrm{NO} \rightarrow \mathrm{NO}_{2}+\mathrm{OH}$

Halogens also oxidize elemental mercury. Our observations have shown that this process occured at Summit during

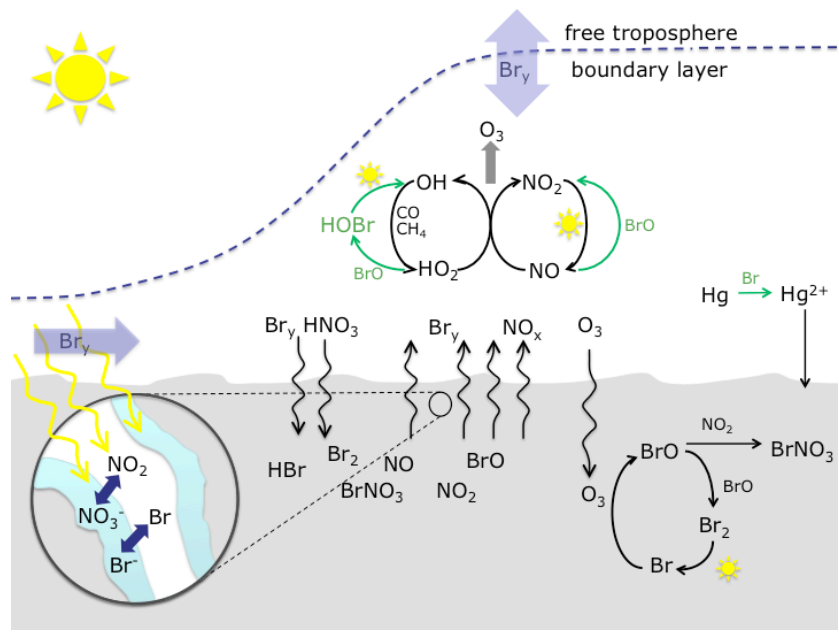

Fig. 1. Sketch of the local processes influencing chemistry of $\mathrm{NO}_{\mathrm{x}}$, $\mathrm{HO}_{\mathrm{x}}$, and reactive bromine over snow. Atmospheric reactions show the basic $\mathrm{HO}_{\mathrm{x}}$ and $\mathrm{NO}_{\mathrm{x}}$ cycles, which ultimately lead to the formation of ozone, as well as the impact of bromine chemistry on these cycles and elemental mercury. The figure illustrates the poorly constrained photochemical source of reactive nitrogen and bromine compounds in the liquid layer on snow crystals and the exchange of trace species between the snow and the atmosphere, which is tied to vertical transport processes. The composition of interstitial air and its gas-phase chemistry has not been well quantified. For example, if present, bromine compounds in the interstitial air would be expected to deplete ozone and react with nitrogen oxides to form bromine nitrate.

GSHOX (see below). The oxidation proceeds via two steps (Reactions 8 and 9), with the second step involving $\mathrm{X}=\mathrm{Br}$, $\mathrm{Cl}$, or $\mathrm{OH}$.

$\mathrm{Br}+\mathrm{Hg} \leftrightarrow \mathrm{BrHg}$

$\mathrm{BrHg}+\mathrm{X} \rightarrow \mathrm{HgBrX}$

Oxidized forms of mercury (e.g. $\mathrm{HgBrX}$ ) are readily deposited to the snowpack causing mercury depletion events (MDEs).

\section{Approach}

Initial plans relied on differential optical absorption spectrometry (DOAS) to attempt direct measurement of $\mathrm{BrO}$, using both active (long path or LP) (Stutz et al., 2011) and passive multi-axis (MAX) DOAS instruments. Our notion was that this combination might provide insight into the relative importance of any bromine emitted from the snow or transported close to the surface of the ice sheet versus bromine mixed downward from aloft. Unfortunately, the retrieval of $\mathrm{BrO}$ profiles from the MAX-DOAS proved unreliable at the low mixing ratios found at Summit. The LP-DOAS measurements (Stutz et al., 2011) were complemented by insitu observations of soluble gas phase bromide both in the 
boundary layer above the snow and in the pore spaces of the snowpack (firn air) (Dibb et al., 2010). Shortly before the 2007 campaign a technique to measure $\mathrm{BrO}$ and several other bromine compounds by chemical ionization mass spectrometry (CIMS) was developed and validated in the laboratory at Georgia Tech. Therefore, it was decided to deploy a CIMS to also attempt direct measurements of reactive bromine at Summit (Liao et al., 2011).

Because $\mathrm{Br}_{\mathrm{y}}$ was expected to be present at Summit in low abundance, if at all, we also deployed systems to measure $\mathrm{HO}_{\mathrm{x}}$ (Liao et al., 2011), speciated $\mathrm{Hg}$ (Brooks et al., 2011), and to collect whole air samples for quantification of a large number of non-methane hydrocarbons (NMHC). These techniques can all provide indirect evidence of bromine chemistry. Observations of $\mathrm{HO}_{\mathrm{x}}$ and the NMHC also serve as strong constraints on box modeling used to assess our understanding of the photochemistry at Summit. We also measured $\mathrm{NO}, \mathrm{O}_{3}$ and actinic flux, and profiled the dynamic state of the boundary layer to support modeling efforts (Liao et al., 2011; Thomas et al., 2011). Size-resolved aerosol number, surface area, and volume distributions (Ziemba et al., 2010) and the ionic composition of bulk aerosol and surface snow (Dibb et al., 2010) were also determined primarily to support the one-dimensional (1-D) modeling described by Thomas et al. (2011, 2012). Table 1 in Liao et al. (2011) summarizes the full suite of chemical measurements that were made during the campaign and additional measurement details are provided in the other papers in this special issue (e.g. tethersonde profiles from 2008 are available in Thomas et al., 2011).

\section{Findings}

Very strong indirect evidence of bromine chemistry was provided by the speciated $\mathrm{Hg}$ measurements within the first week of the 2007 campaign. Mid-day peaks of RGM in excess of $200 \mathrm{pg} \mathrm{m}^{-3}$ were highly correlated with solar radiation (including $\mathrm{J}_{\mathrm{Br}_{2}}$ ) and nearly stoichiometric decreases in GEM (Brooks et al., 2011). Unfortunately, the CIMS instrument was not yet fully on-line (Liao et al., 2011) and the LP-DOAS was suffering significant visibility problems due to the very shallow and stable nighttime inversion (Stutz et al., 2011). Therefore, there is little direct evidence of $\mathrm{Br}_{\mathrm{y}}$ chemistry during the most extreme mercury depletion event observed during either of our campaigns. However, during several smaller MDE later in 2007 and early in the 2008 campaign $\mathrm{BrO}$ mixing ratios were found to increase with RGM (Brooks et al., 2011; Liao et al., 2011; Stutz et al., 2011). Liao et al. (2011) point out that periods with enhanced RGM also exhibit large underestimation of $\mathrm{OH}$ by the box model and find that adding bromine chemistry to the model (constrained by $\mathrm{BrO}$ observations when available) does not resolve the discrepancy between observations and the model.
It is likely that the highest mixing ratios of $\mathrm{BrO}$ at Summit during the two campaigns occurred during the MDE early in 2007 when $\mathrm{BrO}$ measurements were sparse. This was also the time with the lowest temperatures during the two GSHOX experiments at Summit and was characterized by relatively low wind speeds and air masses that were influenced by local processes. Both direct $\mathrm{BrO}$ techniques (CIMS and LP-DOAS) and the measurements of soluble gas phase bromide (soluble $\mathrm{Br}^{-}$) (Dibb et al., 2010) showed decreasing trends through the rest of the 2007 season and even lower abundances through most of the 2008 campaign. Brooks et al. (2011) likewise reported lower peak and mean abundances of RGM in 2008 compared to 2007, but it appears that the relationship between RGM and $\mathrm{BrO}$ was only direct during the colder part of the 2007 season. They suggest that at the low mixing ratios of $\mathrm{BrO}$ characteristic of Summit the radical $\mathrm{HgBr}$ is only likely to further react to form RGM (i.e., $\mathrm{HgBr}_{2}, \mathrm{HgBrOH}, \mathrm{HgBrCl}$ ) before it thermally decomposes if temperatures are below $-15^{\circ} \mathrm{C}$. In the 2008 season daytime temperatures generally exceeded this threshold, and RGM enhancements were only observed early in the morning.

Preliminary analysis of $\mathrm{BrO}$ observations during the 2007 campaign found that on some days mixing ratios began increasing in the early morning, decreased markedly in the early afternoon and then increased again in the early evening. Diurnal behavior of NO was similar, with the mid-day decrease more clearly defined due to higher mixing ratios in general. Both trends could be reflecting the influence of boundary layer dynamics on gas concentrations if the primary source of bromine is release from the snowpack, as is established for $\mathrm{NO}_{\mathrm{x}}$. Two days of firn air sampling in 2007 confirmed that soluble $\mathrm{Br}^{-}$was definitely higher in the firn air than in the air above the snow (Dibb et al., 2010), providing some support for the viability of the snow pack as a source of reactive bromine. Further analysis of the 2007 data inspired more effort to characterize boundary layer evolution and dynamics (e.g., see the tethersonde profiles in Thomas et al., 2011), as well as much more firn air sampling, during the 2008 campaign. It is now quite clear that the snowpack is an important source of reactive bromine at Summit (Dibb et al., 2010) and is essentially the only source that needs to be considered when transport is weak (Stutz et al., 2011). Further support for this conclusion is provided by the successful simulation of both $\mathrm{BrO}$ and NO by the 1-D coupled atmospheresnow model MISTRA-SNOW (Thomas et al., 2011). The model assumed that snow photochemistry was the source of $\mathrm{NO}$ and $\mathrm{BrO}$ and was evaluated using a case study when the airmasses arriving at Summit had been over the Greenland ice sheet at low altitude for the previous 3 days.

Stutz et al. (2011) present very simple steady state calculations which indicate that the measured low mixing ratios of $\mathrm{BrO}$ should only increase the $\mathrm{OH} / \mathrm{HO}_{2}$ ratio on the order of $20 \%$ under the low NO conditions characteristic of Summit. Sensitivity studies with MISTRA-SNOW find that setting the concentration of $\mathrm{Br}^{-}$in the snow to zero (shutting 
off the only source of active bromine in the model) increases $\mathrm{OH}$ just above the snow by $6-20 \%$ depending on time of day (Thomas et al., 2012). Similarly, using a box model that includes bromine chemistry constrained by measured $\mathrm{BrO}$ from the CIMS, average midday (10:00-14:00 LT) $\mathrm{OH}$ increases by 12 and $10 \%$ for the 2007 and 2008 campaigns, respectively (Liao et al., 2011). Using BrO from the LP-DOAS to constrain the box model results in 10 and $4 \%$ increases of average modeled $\mathrm{OH}$. It should be noted that the box model calculations used all time periods that included $\mathrm{BrO}$ observations from either of the instruments, rather than restricting attention to times when both the CIMS and LP-DOAS reported values. The larger impact on modeled $\mathrm{OH}$ when constrained by $\mathrm{BrO}$ from the CIMS is therefore not necessarily due to a consistent bias between the CIMS and LP-DOAS. Also, in all cases measured $\mathrm{OH}$ was generally still higher than any of the modeled values that included bromine chemistry, but within the combined uncertainties of the measurements and model estimates.

With the snowpack established as a major source of $\mathrm{Br}_{\mathrm{y}}$ just above the snow, one must wonder about the source(s) providing bromine and/or bromide to the snow. Seasalt or modified seasalt from the north Atlantic would seem a likely source, but rapid transport from the marine boundary layer to Summit is relatively rare during summer. Sjostedt et al. (2007) describe one such event in 2003 and two similar cases were observed during the 2008 campaign (Liao et al., 2011; Stutz et al., 2011). Dibb et al. (2010) found that the mean concentration of $\mathrm{Br}^{-}$in the surface layer of snow during 2007 was twice that in 2008, quite similar to observed differences in mean mixing ratios of $\mathrm{BrO}$ measured by LP-DOAS (Stutz et al., 2011) and soluble $\mathrm{Br}^{-}$(Dibb et al., 2010); Liao et al. (2011) reported similar mean BrO mixing ratios from the CIMS in the two years but noted that the record in 2007 did not begin until 27 May. Dibb et al. (2010) reported significant variability in the $\mathrm{Br}^{-}$concentration in surface snow over the $\sim 6$-week long campaigns in both years. In addition, the intervals with enhanced $\mathrm{Br}^{-}$concentration tended to coincide with elevated concentrations of the radionuclide tracers ${ }^{7} \mathrm{Be}$ and ${ }^{210} \mathrm{~Pb}$ (monitored as part of Summit station baseline observations, Dibb, 2007). Previous work has shown that these tracers are controlled, to first order, by alternating ventilation/isolation of the boundary layer at Summit with stronger vertical mixing (ventilation) bringing free tropospheric air with higher concentrations of ${ }^{7} \mathrm{Be}$ and ${ }^{210} \mathrm{~Pb}$ to the surface. The correlation with $\mathrm{Br}^{-}$in snow suggests that a free tropospheric pool of bromine is supplying the surface snow during the summer.

Although the concentrations of $\mathrm{Br}^{-}$in summer surface snow at Summit are very low $\left(<0.4 \mathrm{pmol} \mathrm{mol}^{-1}\right)$, the $\mathrm{Br}^{-} / \mathrm{Na}^{+}$ratio is several orders of magnitude larger than that in seasalt (Dibb et al., 2010). Similar enrichments of $\mathrm{Br}^{-}$in aerosol and snow have been observed in association with ozone depletion events in both the Arctic basin and coastal Antarctica. It may be that the source of bromine in the free troposphere over Summit is the Arctic basin (Fig. 2). Three processes may contribute to bromine loading at Summit, which likely originates from bromine explosion events. First, transport to Summit from bromine in the Arctic marine boundary layer may occur via processes in the free troposphere. For example, this could occur via convection over open leads (narrow openings in the sea ice cover) followed by processing of bromine in the free troposphere and then deposition at Summit. Second, it is possible, but less likely, that processing of bromine via snowpack chemistry within the boundary layer that results in net bromide transport towards Summit occurs (demonstrated as uptake and release of bromide in the BL in Fig. 2), which would commence at polar sunrise. These two ongoing processes, if important, are likely overlaid on the third mechanism, episodic rapid transport of high bromine air masses to Summit, which has been observed (e.g. Stutz et al., 2011), but remains uncertain as to the frequency and amount of bromine transported. It is likely that both wet and dry deposition contribute to bromine loading at Summit. These processes are modulated by seasonal changes in the available sunlight, boundary layer stability, and rates of exchange between the boundary layer and the free troposphere. After initial deposition, photochemical cycling and re-release of bromine from the snowpack to the polar boundary layer is now known to occur at Summit in late spring and summer along with nitrate/ $\mathrm{NO}_{\mathrm{x}}$ cycling and mercury oxidation (see Fig. 1). However, year-round sampling at Summit from August 2000 through August 2002 found no evidence for active halogen chemistry (via perturbed NMHC ratios) or effective transport of Arctic Haze into central Greenland (Dibb et al., 2007). It has been suggested that vertical mixing can loft activated $\mathrm{Br}_{\mathrm{y}}$ out of the boundary layer over the sea ice in April (McElroy et al., 1999; Salawitch et al., 2010) and that vertical mixing of the entire free troposphere becomes more vigorous through late spring into early summer (e.g., Scheuer et al., 2003). We therefore speculate that bromine activation in the Arctic basin just after sunrise and throughout the spring provides most of the $\mathrm{Br}^{-}$that later mixes down to the surface at Summit, but recognize that the delay between sunrise in March and delivery to Summit in May is not fully understood.

\section{Conclusions}

The GSHOX campaigns have confirmed that active $\mathrm{Br}_{\mathrm{y}}$ chemistry is occurring in and above the snow in the center of the Greenland ice sheet. During the summers of 2007 and 2008 emissions from the snowpack appear to have been the dominant source of active $\mathrm{Br}_{\mathrm{y}}$, sufficient to sustain observed mixing ratios and cycling of active bromine compounds. The current knowledge (including poorly characterized processes) of bromine cycling between the snow and atmosphere at Summit, connection to other chemical cycles known to occur, and physical processes that determine 


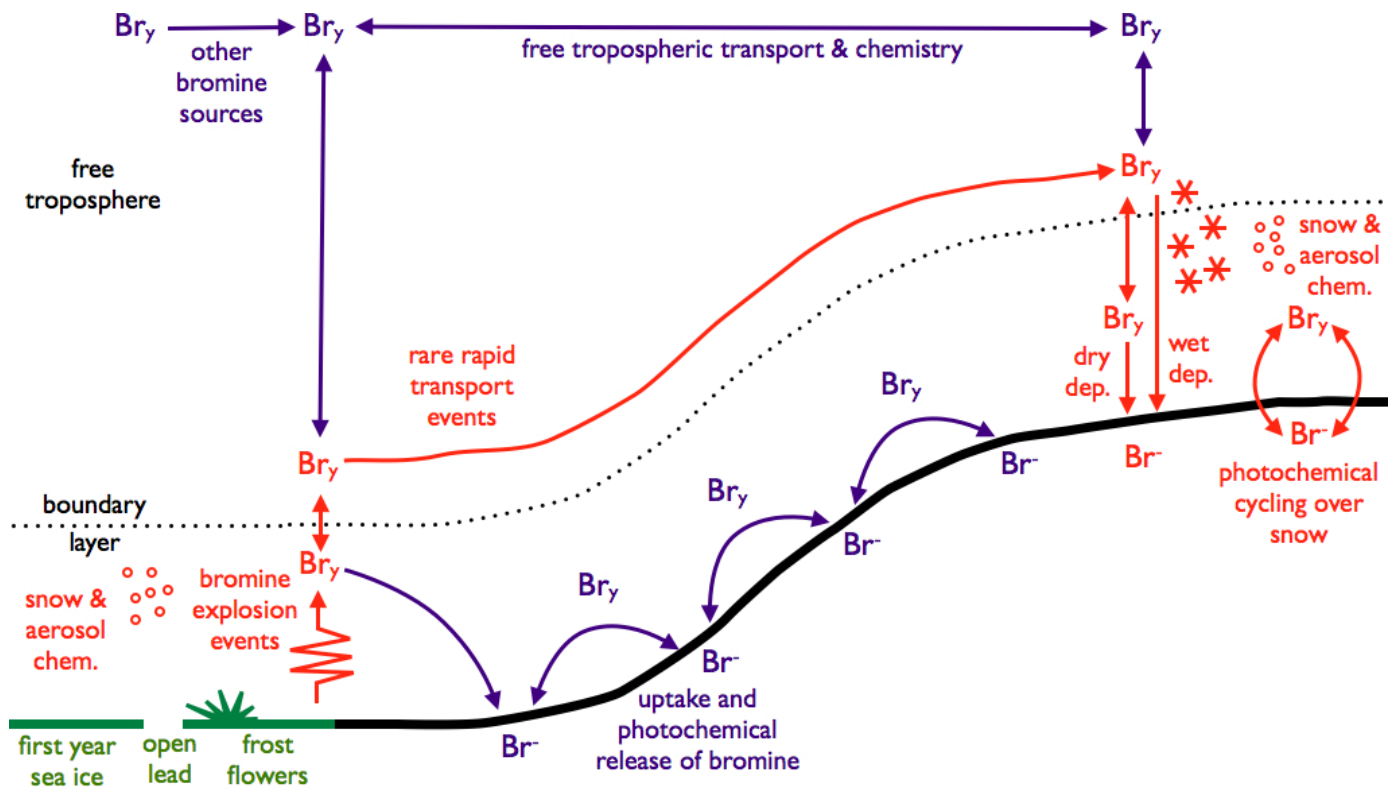

coastal Arctic

coastal snowpack

remote snowpack

Summit, Greenland

Fig. 2. Schematic of the current understanding of chemical cycling of bromine at Summit and the connections to known bromine sources. We use $\mathrm{Br}_{\mathrm{y}}$ to refer to both gas and aerosol bromine in the boundary layer and troposphere. Chemical cycling known to occur is shown in red, processes or may occur are shown in purple. Many of the processes in red in have large uncertainties as to their role in tropospheric chemistry as well as their contributing to bromine cycling at Summit. When bromine explosion events occur transport of bromine to Summit may occur via a number of currently poorly characterized pathways and in a number of forms. The source of bromine at Summit is uncertain and should be further studied. In addition, the form of bromine initially deposited to the surface snowpack should be characterized.

boundary layer concentrations are shown in Fig. 1. Mixing ratios of $\mathrm{BrO}$ in the low pptv range and inferred (modeled) levels of other active bromine compounds improve the agreement between measured and modeled $\mathrm{OH}$, but do not fully account for model underestimates. However, these small abundances of active bromine compounds do seem to cause significant conversion of GEM to RGM when temperatures are below $-15{ }^{\circ} \mathrm{C}$. The source of bromide in the snow required to sustain active bromine chemistry at Summit is not well constrained. However, the correlation of enhanced surface $\mathrm{Br}^{-}$with radionuclide tracers suggests a free tropospheric pool of $\mathrm{Br}_{\mathrm{y}}$ may be supplying bromide to surface snow during the summer.

Our field experiments and subsequent analysis have identified a number of unresolved issues and uncertainties in the understanding of the snow-air chemistry and transport system at Summit. While we have clearly shown the presence of reactive bromine on the Greenland ice sheet, it is unclear if bromine chemistry is also active in other snow-covered areas, for example the Antarctic ice sheet, that are far removed from known halogen reservoirs. Our ability to extrapolate our findings to other environments that are removed from the likely oceanic source of bromine is also hindered by the fact that we currently do not understand how, and in which form, bromine is transported to the center of the Greenland ice sheet. The uncharacterized transport pathways should be fur- ther investigated, (see Fig. 2) including: (1) Bromine could be transported in the boundary layer, for example through a process in which bromine is continuously released from and deposited to the snow surface while being slowly transported from the marine boundary layer to Summit. This mechanism could be particularly important during spring, when the stable boundary layer inhibits exchange with the free troposphere and when the well known bromine explosions release large amounts of $\mathrm{Br}_{\mathrm{y}}$ from the Arctic sea ice. (2) Transport via exchange of bromine from the boundary layer to the free troposphere from bromine explosion events, followed by transport in the free troposphere and either dry or wet deposition to the snow at Summit. Investigation of these two uncharacterized transport pathways should be combined with understanding the frequency and quantity of bromine transported to Summit in rapid transport events from coastal regions. We have shown that reactive nitrogen and bromine species are formed in the snow and released to the atmosphere at Summit, consistent with prior work at this site. However, the vertical transport of trace gases in the snow, as well as their transfer into and out of the boundary layer remain poorly constrained. More research is needed to accurately quantify and parameterize these transport processes and their dependence on environmental parameters, such as snow and atmospheric temperature profiles, snow morphology, wind speed, etc. Additional studies characterizing free 
tropospheric and boundary layer $\mathrm{Br}_{\mathrm{y}}$ (including speciation and concentrations) in the Arctic are clearly warranted. The chemistry in the snow pack has significant uncertainties, in particular with respect to the multiphase chemistry on the snow surface. The thickness and composition of the liquid layer present on snow remains uncertain. This is one of the many challenges confronting the development of quantitative modeling tools to describe the uptake, chemistry, and release of reactive species from snow. Targeted laboratory studies to improve our knowledge of this chemistry and better measurements of the composition of interstitial air in the field are both essential in the future.

The uncertainties limit our ability to fully quantify how processes, such as transport, deposition, and chemical recycling in and above snow, modulate nitrogen, halogen, and $\mathrm{HO}_{\mathrm{x}}$-radical chemistry as well as ozone levels in polar environments.

Acknowledgements. The research described herein was financially supported by the NSF GEO ATM tropospheric chemistry program, with logistical support from NSF OPP ARSL through their contractor CPS. The assistance from CPS field staff was outstanding and is greatly appreciated. Heavy airlift by the NY ANG was essential to field our large group, and to sustain the operation of the Summit station. We are grateful that the Greenland Home Rule Government and the Danish Polar Center granted us permission to work at Summit.

Edited by: J. Abbatt

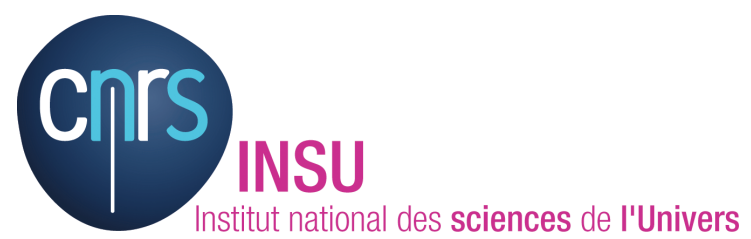

The publication of this article is financed by CNRS-INSU.

\section{References}

Brooks, S., Moore, C., Lew, D., Lefer, B., Huey, G., and Tanner, D.: Temperature and sunlight controls of mercury oxidation and deposition atop the Greenland ice sheet, Atmos. Chem. Phys., 11, 8295-8306, doi:10.5194/acp-11-8295-2011, 2011.

Chen, G., Huey, L. G., Crawford, J. H., Olsen, J. R., Hutterli, M. A., Sjostedt, S., Tanner, D., Dibb, J., Lefer, B., Blake, N., Davis, D., and Stohl, A.: An assessment of the the polar $\mathrm{HO}_{\mathrm{x}}$ budget based on 2003 Summit Greenland field observations, Atmos. Environ., 41, 7806-7828, doi:10.1016/j.atmosenv.2007.06.014, 2007.

Choi, S., Wang, Y., Salawitch, R. J., Canty, T., Joiner, J., Zeng, T., Kurosu, T. P., Chance, K., Richter, A., Huey, L. G., Liao, J., Neuman, J. A., Nowak, J. B., Dibb, J. E., Weinheimer, A. J., Diskin, G., Ryerson, T. B., da Silva, A., Curry, J., Kinnison, D., Tilmes, S., and Levelt, P. F.: Analysis of satellite-derived Arctic tropospheric $\mathrm{BrO}$ columns in conjunction with aircraft measurements during ARCTAS and ARCPAC, Atmos. Chem. Phys., 12, 12551285, doi:10.5194/acp-12-1255-2012, 2012.

Davis, D., Nowak, J. B., Chen, G., Buhr, M., Arimoto, R., Hogan, A., Eisele, F., Mauldin, L., Tanner, D., Shetter, R., Lefer, B., and McMurry, P.: Unexpected high levels of NO observed at South Pole, Geophys. Res. Lett., 28, 3625-3628, 2001.

Dibb, J. E.: Vertical mixing above Summit, Greenland: Insights into seasonal and high frequency variability from the radionuclide tracers ${ }^{7} \mathrm{Be}$ and ${ }^{210} \mathrm{~Pb}$, Atmos. Environ., 41, 5020-5030, doi:10.1016/j.atmosenv.2006.12.005, 2007.

Dibb, J. E., Albert, M., Courville, Z., Anastasio, C., Galbavy, E. S., Atlas, E., Beyersdorf, A. J., Blake, D. R., Meinardi, S., Rowland, F. S., Swanson, A. L., Blake, N. J., Bocquet, F., Cohen, L., Helmig, D., Burkhart, J. F., Frey, M. M., Friel, D. K., Hutterli, M. A., Chen, G., Conway, T. J., and Oltmans, S. J.: An overview of air-snow exchange at Summit, Greenland: recent experiments and findings, Atmos. Environ., 41, 4995-5006, doi:10.1016/j.atmosenv.2006.12.006, 2007.

Dibb, J. E., Ziemba, L. D., Luxford, J., and Beckman, P.: Bromide and other ions in the snow, firn air, and atmospheric boundary layer at Summit during GSHOX, Atmos. Chem. Phys., 10, 99319942, doi:10.5194/acp-10-9931-2010, 2010.

Grannas, A. M., Jones, A. E., Dibb, J., Ammann, M., Anastasio, C., Beine, H. J., Bergin, M., Bottenheim, J., Boxe, C. S., Carver, G., Chen, G., Crawford, J. H., Dominé, F., Frey, M. M., Guzmán, M. I., Heard, D. E., Helmig, D., Hoffmann, M. R., Honrath, R. E., Huey, L. G., Hutterli, M., Jacobi, H. W., Klán, P., Lefer, B., McConnell, J., Plane, J., Sander, R., Savarino, J., Shepson, P. B., Simpson, W. R., Sodeau, J. R., von Glasow, R., Weller, R., Wolff, E. W., and Zhu, T.: An overview of snow photochemistry: evidence, mechanisms and impacts, Atmos. Chem. Phys., 7, 43294373, doi:10.5194/acp-7-4329-2007, 2007.

Honrath, R. E., Peterson, M. C., Guo, S., Dibb, J. E., Shepson, P. B., and Campbell, B.: Evidence of $\mathrm{NO}_{\mathrm{x}}$ production within or upon ice particles in the Greenland snowpack, Geophys. Res. Lett., 26, 695-698, 1999.

Honrath, R. E., Peterson, M. C., Lu, Y., Dibb, J. E., Arsenault, M. A., Cullen, N. J., and Steffen, K.: Vertical fluxes of $\mathrm{NO}_{\mathrm{x}}$, HONO and $\mathrm{HNO}_{3}$ above the snowpack at Summit, Greenland, Atmos. Environ., 36, 2629-2640, 2002.

Jones, A. E., Weller, R., Wolff, E. W., and Jacobi, H.-W.: Speciation and Rate of Photochemical $\mathrm{NO}$ and $\mathrm{NO}_{2}$ Production in Antarctic Snow, Geophys. Res. Lett., 27, 345-348, 2000.

Liao, J., Huey, L. G., Tanner, D. J., Brough, N., Brooks, S., Dibb, J. E., Stutz, J., Thomas, J. L., Lefer, B., Haman, C., and Gorham, $\mathrm{K}$.: Observations of hydroxyl and peroxy radicals and the impact of BrO at Summit, Greenland in 2007 and 2008, Atmos. Chem. Phys., 11, 8577-8591, doi:10.5194/acp-11-8577-2011, 2011.

McElroy, C. T., McLinden, C. A., and McConnell, J. C.: Evidence for bromine monoxide in the free troposphere during the Arctic polar sunrise, Nature, 397, 338-341, 1999.

Ridley, B., Walega, J., Montzka, D., Grahek, F., Atlas, E., Flocke, F., Stroud, V., Deary, J., Gallant, A., Bottenheim, J., Anlauf, K., Worthy, D., Sumner, A. L., Splawn, B., and Shepson, P. B.: Is the Arctic surface layer a source and sink of $\mathrm{NO}_{\mathrm{x}}$ in winter/spring?, J. Atmos. Chem., 36, 1-22, 2000.

Roscoe, H. K., Brough, N., Jones, A. E., Wittrock, F., Richter, A., Van Roozendael, M., and Hendrick, F.: Resolution of an important discrepancy between remote and in-situ measurements of 
tropospheric BrO during Antarctic enhancements, Atmos. Meas. Tech. Discuss., 5, 5419-5448, doi:10.5194/amtd-5-5419-2012, 2012.

Salawitch, R. J., Canty, T., Kurosu, T., Chance, K., Liang, Q., da Silva, A., Pawson, S., Nielsen, J. E., Rodriguez, J. M., Bhartia, P. K., Liu, X., Huey, L. G., Liao, J., Stickel, R. E., Tanner, D. J., Dibb, J. E., Simpson, W. R., Donohoue, D., Weinheimer, A., Flocke, F., Knapp, D., Montzka, D., Neuman, J. A., Nowak, J. B., Ryerson, T. B., Oltmans, S., Blake, D. R., Atlas, E. L., Kinnison, D. E., Tilmes, S., Pan, L. L., Hendrick, F., Van Roozendael, M., Kreher, K., Johnston, P. V., Gao, R. S., Johnson, B., Bui, T. P., Chen, G., Pierce, R. B., Crawford, J. H., and Jacob, D. J.: A new interpretation of total column $\mathrm{BrO}$ during Arctic spring, Geophys. Res. Lett., 37, L21805, doi:10.1029/2010GL043798, 2010.

Scheuer, E., Talbot, R. W., Dibb, J. E., Seid, G. K., DeBell, L., and Lefer, B.: Seasonal distributions of fine aerosol sulfate in the North American Arctic basin during TOPSE, J. Geophys. Res., 108, 8370, doi:10/1029/2001JD001364, 2003.

Sjostedt, S. J., Huey, L. G., Tanner, D. J., Pieschl, J., Chen, G., Dibb, J. E., Lefer, B., Hutterli, M. A., Beyersdorf, A. J., Blake, N. J., Blake, D. R., Sueper, D., Ryerson, T., Burkhardt, J. and Stohl, A.: Observations of hydroxyl and the sum of peroxy radicals at Summit, Greenland during summer 2003, Atmos. Environ., 41, 5122-5137, doi:10.1016/j.atmosenv.2006.06.065, 2007.

Stutz, J., Thomas, J. L., Hurlock, S. C., Schneider, M., von Glasow, R., Piot, M., Gorham, K., Burkhart, J. F., Ziemba, L., Dibb, J. E., and Lefer, B. L.: Longpath DOAS observations of surface BrO at Summit, Greenland, Atmos. Chem. Phys., 11, 9899-9910, doi:10.5194/acp-11-9899-2011, 2011.
Thomas, J. L., Stutz, J., Lefer, B., Huey, L. G., Toyota, K., Dibb, J. E., and von Glasow, R.: Modeling chemistry in and above snow at Summit, Greenland - Part 1: Model description and results, Atmos. Chem. Phys., 11, 4899-4914, doi:10.5194/acp-11-48992011, 2011.

Thomas, J. L., Dibb, J. E., Huey, L. G., Liao, J., Tanner, D., Lefer, B., von Glasow, R., and Stutz, J.: Modeling chemistry in and above snow at Summit, Greenland - Part 2: Impact of snowpack chemistry on the oxidation capacity of the boundary layer, Atmos. Chem. Phys., 12, 6537-6554, doi:10.5194/acp-12-65372012, 2012.

Theys, N., Van Roozendael, M., Hendrick, F., Yang, X., De Smedt, I., Richter, A., Begoin, M., Errera, Q., Johnston, P. V., Kreher, K., and De Mazière, M.: Global observations of tropospheric BrO columns using GOME-2 satellite data, Atmos. Chem. Phys., 11, 1791-1811, doi:10.5194/acp-11-1791-2011, 2011.

Yang, J., Honrath, R. E., Peterson, M. C., Dibb, J. E., Sumner, A. L., Shepson, P. B., Frey, M., Jacobi, H.-W., Swanson, A., and Blake, N.: Impacts of snowpack photochemistry on levels of $\mathrm{OH}$ and peroxy radicals at Summit, Greenland, Atmos. Environ., 36, 2523-2534, 2002.

Ziemba, L. D., Dibb, J. E., Griffin, R. J., Huey, L. G., and Beckman, P.: Observations of particle growth at a remote Arctic site, Atmos. Environ., 44, 1649-1657, doi:10.1016/j.atmosenv.2010.01.032, 2010. 